\title{
O teclado das paixões em cena: Relatos Selvagens e o elo retórico-musical
}

\author{
Valmir Ferreira dos Santos Junior \\ Graduando em Letras pela Universidade de Franca (UNIFRAN), Brasil. \\ valmirferreiradossantosjunior@gmail.com \\ Maria Flávia Figueiredo \\ Professora Doutora da Universidade de Franca (UNIFRAN), Brasil. \\ mariaflaviafigueiredo@yahoo.com.br
}

Resumo: A música detém um caráter altamente envolvente. Conhecimento não tão usual como esse é o de que a música pode objetivar diversos fins argumentativo-persuasivos no que tange às áreas do discurso. Particularmente, a trilha sonora constitui um elemento muito significativo quando aliada às cenas de uma peça cinematográfica. A trilha sonora do sexto episódio de Relatos Selvagens (filme de 2014, dirigido por Damián Szifron), juntamente com as demais linguagens que a acompanham, constitui o corpus do nosso trabalho. O objetivo deste artigo é evidenciar a relação cena-trilha sonora e como tal elo atua em um discurso multimodal de forma argumentativa. Contaremos com conceitos oriundos da teoria musical (como andamento e timbre) e da Retórica (figuras e paixões aristotélicas). Esperamos, por meio de uma análise qualitativa dos dados, desvelar os sentidos criados por meio da inter-relação cena-trilha sonora e os possíveis desdobramentos no que concerne ao pathos (esfera do espectador).

Palavras-chave: Retórica. Música. Figuras Retóricas. Paixões Aristotélicas.

\begin{abstract}
The Music sphere is well known by its powerful engaging character. Not as usual as the idea above is that music can be used to achieve several argumentativepersuasive ends. Moreover, the soundtrack constitutes a significant element when combined with the scenes of a movie. The soundtrack of the sixth episode of the Wild Tales (2014) motion picture, along with the other languages that accompany it, constitute the corpus of our paper. The objective of this article is to highlight the image-sound relationship, as well as to deflagrate how such bond acts in an argumentative multimodal discourse. In order to achieve this, the concepts derived from musical theory (such as tempo and timbre) and Rhetoric (Aristotelian figures and passions) will aid us. We expect, through a qualitative analysis of the data, to unveil the meanings created by the interrelation between scene-soundtrack and the possible discoveries regarding pathos (sphere of the audience).
\end{abstract}

Keywords: Rhetoric. Music. Figure of Speech. Aristotle’s Passions. 
As paixões constituem um teclado no qual o bom orador toca para convencer. Michel Meyer

Introdução

O papel da trilha sonora em uma película fílmica é inerente quanto ao seu valor e significado. A história nos mostra em seu percurso que, em contextos cênicos, o som e a imagem sempre possuíram uma conexão intrínseca. De fato, ao buscar por evidências na história da humanidade, é possível deflagrar que a relação imagem-som, independente das limitações ou avanços tecnológicos da época, é infinitamente explorada. A tragédia grega é um dos diversos exemplos que podemos adotar para discutir sobre tal relação. Em A Poética, Aristóteles descreve o uso dos cânticos que acompanhavam e completavam as "cenas" que eram apresentadas nas dionísias urbanas ${ }^{1}$, que traziam concursos de tragédia. Tomando outro marco dos primórdios cênicos como exemplo, o cinema mudo se caracteriza como outra prova que denota a relação complementar e indissociável de imagem e som. De fato, tais produções não eram completamente silenciosas, algum acompanhamento musical era sempre executado - por pianistas ou, com o avanço da tecnologia, por discos contendo a "trilha sonora" do filme ajudando a projetar a atmosfera da cena à plateia.

Esses exemplos evidenciam que, para a plateia, é estranho - em contextos dramatúrgicos - ter a presença de imagem sem som, ou de som desacompanhado de imagem. Essa junção tem, dentre diversos intuitos, o de ampliar a dramaticidade da cena por meio dos elementos sonoros selecionados; criar novos significados por meio da equação cena mais trilha sonora; e instigar emoções no auditório por meio de estímulos imagéticos e sonoros, despertando e exaltando as emoções disponíveis na plateia dessas produções cinematográficas.

Pela mesma perspectiva, nosso trabalho fita desvelar de que forma as paixões, tal como Aristóteles as entende², podem ser despertadas no auditório por meio da relação cena-trilha sonora, ressaltando que tais paixões

\footnotetext{
${ }^{1}$ Dionísias Urbanas eram uma das mais importantes festas religiosas de Atenas. Dedicadas ao deus Dioniso, eram celebradas todos os anos no início da primavera. (MALHADAS, 2003, p. 67).

${ }^{2}$ Para Aristóteles, as paixões são movimentos que atuam na alma. Caracterizam-se também como uma qualidade segundo a qual uma coisa pode ser alterada: o branco pode tornar-se preto, o leve, pesado, etc. (cf. ARISTOTLE'S METAPHYSICS, Book V, Chap. XXI).
} 
$\mathrm{EI} \square \AA \mathrm{A}$

Revista Eletrônica de Estudos Integrados em Discurso e Argumentação, Ilhéus, n. 17, jul./dez. 2018

só são evocadas em um auditório passível e disponível a elas, por meio do contexto situacional ou pela pré-disposição emocional ${ }^{3}$.

Almejamos, então, por meio da análise retórica - que irá nos auxiliar a deflagrar as paixões aristotélicas de forma mais embasada - aliada a teoria musical - que nos auxiliará a descrever e compreender os recursos sonoros que compõem a trilha sonora do corpus selecionado -, desvendar o universo do pathos na música, mais precisamente, entender como as paixões disponíveis no auditório podem ser suscitadas por meio da relação cena-trilha sonora de um filme.

Para que isso seja possível, selecionamos, como corpus do nosso trabalho, o sexto episódio do filme argentino de 2014, Relatos Selvagens. Serão analisadas, mais precisamente, as cenas que são acompanhadas por trilha sonora: os trechos retórico-musicais desse episódio da película, intitulado "Até que a morte nos separe".

\section{Descrição do Corpus}

O episódio final do filme argentino Relatos Selvagens (2014) representa fielmente todo o espectro passional e situacional mantido durante todos os episódios anteriores, abordando situações surreais, em que as personagens se deixam levar pelos seus mais primitivos impulsos. A trama apresenta trágicos acontecimentos que levam a um encerramento inesperado, traduzindo a vida humana de forma sublime ao universo fílmico.

No que concerne às paixões aristotélicas, o filme mostra exemplos perfeitos de como a psyche humana é comovida e tomada pelas afecções, transformando e modelando o julgamento racional. Isso é representado de forma bem clara em todas as linguagens da narrativa, seja no roteiro, na fotografia etc. Porém, salta aos olhos - e aos ouvidos - a forma como as cenas dialogam com a trilha sonora para criar sentidos ou ampliar os significados da trama.

Essa relação cena-trilha sonora é capaz de estender suas projeções semânticas ao auditório, possibilitando o despertar de suas paixões. Ou seja,

\footnotetext{
3 De acordo com Martins (1999, p. 62), "pathos [paixões] na sua origem é principalmente disposição afetiva fundamental”, ou seja, refere-se às emoções disponíveis na instância do auditório.
} 


\section{$\mathrm{EI} \square \mathrm{\alpha A}$}

Revista Eletrônica de Estudos Integrados em Discurso e Argumentação, Ilhéus, n. 17, jul./dez. 2018

essa junção - de cena + trilha sonora - amplia sentidos, cria novos significados e confere novas leituras ao filme. ${ }^{4}$

O episódio Até que a morte nos separe narra as desventuras de um casal em sua festa de casamento. Na sucessão de acontecimentos, a noiva (interpretada por Érica Rivas) descobre que seu marido (caracterizado por Diego Gentile) foi infiel, traindo-a com uma colega do trabalho. Esse fato, então, tira a esposa de seu estado racional, deixando-a furiosa, o que a faz desencadear uma série de trágicos acontecimentos em sua comemoração trai o marido com o cozinheiro; ameaça tornar a vida de seu cônjuge um inferno; e até ataca a mulher com quem seu marido teve um caso.

As personagens protagonistas encarnam com muita tenacidade as afecções que as acometem, podendo projetar toda a expressividade e emoção dos acontecimentos no auditório. Ao longo da trama, a trilha sonora também tem um papel essencial para a projeção de sentimentos que possivelmente se imprimirão nos espectadores, aliando-se às cenas e criando a atmosfera que o roteiro preconiza.

Para que seja possível observar de que forma a trilha sonora se alia ao campo imagético e amplia as afecções no auditório, observaremos os momentos da trama que possuem essa relação cena-trilha sonora, tentando vincular os sentidos visuais e sonoros às paixões aristotélicas. Segue a descrição da trilha sonora presente no episódio em questão:

1. Titanium (David Guetta featuring Sia Furler) - gênero musical: house/ urban-dance;

2. Babel short and dialog (Gustavo Santaolalla) - gênero musical: klezmer;

3. An der schönen, blauen Donau (Johann Strauss II) - gênero musical: valsa;

4. Efeito sonoro relevante: Sirene de ambulância;

5. Efeito sonoro relevante: Trovão;

6. Shalom Aleichem + Tema seguinte - gênero musical: klezmer; e

7. Fly me to the moon (Bobby Womack) - gênero musical: Rhythm and Blues.

\footnotetext{
${ }^{4}$ Os recortes do corpus em que a relação cena-trilha sonora puderem ocasionar o despertar de paixões no auditório serão denominados, neste artigo, trechos retórico-musicais.
} 


\section{EIDळA}

Revista Eletrônica de Estudos Integrados em Discurso e Argumentação, Ilhéus, n. 17, jul./dez. 2018

Aliar a junção de cena-trilha sonora ao universo do pathos só será viável uma vez que compreendermos alguns conceitos da teoria musical e retórica (particularmente a retórica das paixões). Os itens a seguir concernem a tais esferas do saber e seus conceitos.

\section{Teoria Musical}

De acordo com Copland (1974), podemos desmembrar, com intuito analítico, a música em quatro elementos: melodia; harmonia; ritmo; e timbre. A junção arranjada e ordenada desses elementos, em harmonia entre si, compõe o que denominamos música. Cada uma dessas instâncias, dentro da música, é caracterizada como um fator essencial para a compreensão e interpretação da expressividade musical de uma peça. Um ritmo composto acelerado de uma canção indígena, por exemplo, passa uma expressividade totalmente diferente de um ritmo marcado e repetitivo de uma marcha, e o mesmo acontece com todos os outros elementos. As escolhas musicais de uma composição ditam a expressividade e, por consequência, seu significado ou tema fundamental.

Ao ouvinte comum, pouco importa cada um desses elementos de forma distinta, o que normalmente escuta é o conjunto dos quatro, compondo um tecido sonoro, que cria o efeito capaz de chamar a atenção dos ouvintes (BENNETT, 1998, p. 12).

A melodia, de acordo com Copland (1974), está relacionada à ideia de uma emoção íntima. Apesar de caracterizar-se como um elemento primário na Música, a melodia tem um poder arrebatador, uma vez que sua força é capaz de comover por meio de sua expressividade. Bennett (1998, p. 11) aprofundase ainda mais na caracterização da melodia, definindo-a como: "sequência de notas, de diferentes sons, organizadas numa dada forma de modo a fazer sentido musical para quem escuta".

Para compreendermos melhor a harmonia, podemos nos basear no raciocínio de Bennett (1998, p. 11-12), que afirma:

\footnotetext{
A harmonia ocorre quando duas ou mais notas de diferentes sons são ouvidas ao mesmo tempo, produzindo um acorde. Usamos a palavra "harmonia" de duas maneiras: para nos referirmos à seleção de notas que constituem determinado acorde e, em sentido lato, para descrevermos o desenrolar ou a progressão dos acordes durante toda uma composição.
} 
O ritmo pode ser percebido ao fundo de uma peça, por meio da pulsação rítmica. Esse elemento tem um poder inerente na expressividade musical, visto a forma com que enlaça e toma as emoções do ouvinte. Para que essa definição fique um pouco mais clara, podemos nos basear nas palavras de Bennett (1998, p. 12) que caracteriza o ritmo como "diferentes modos pelos quais um compositor agrupa os sons musicais, principalmente do ponto de vista da duração dos sons e de sua acentuação".

Na categoria ritmo, temos duas formas de classificação: uma delas é o conceito de BPM (batidas por minuto) e a outra se refere aos termos em italiano que ditam o passo em que o intérprete deve tocar uma peça. Tais formas de classificação serão fundamentais em nossa análise, uma vez que, sempre que necessário, relacionaremos o BPM das músicas que compõem o corpus à nomenclatura italiana de andamento ${ }^{5}$ para vincular a descrição das paixões aristotélicas ao ritmo da música.

A seguir veremos um quadro com os termos em italiano e suas respectivas representações em BPM:

Quadro 1 - Classificação dos andamentos

\begin{tabular}{|c|c|c|}
\hline Termos em italiano & BPM & Definição \\
\hline Allegretto & $112-120$ & Não tão depressa quanto allegro \\
\hline Allegro & $120-168$ & Ligeiro, alegre, feliz, animado \\
\hline Vivace & $152-168$ & Rápido e vivo, com vivacidade \\
\hline Vivacissimo & $168-180$ & Mais vivo que vivace \\
\hline Presto & $168-200$ & Veloz e animado \\
\hline Prestissimo & $200-208$ & Com toda velocidade \\
\hline
\end{tabular}

Fonte: Elaborado pelo autor com base em BENETT, 1998.

E, por fim, em relação ao timbre, podemos classificá-lo como o "colorido tonal" de um instrumento, ou seja, as qualidades e propriedades sonoras que um instrumento possui e que são responsáveis pelo reconhecimento de determinado instrumento.

\footnotetext{
${ }^{5}$ Define-se como andamento a velocidade do compasso em uma peça. Em italiano esse termo é visto como tempo marcado nas partituras para guiar sua execução. Além dos termos em italiano, o compositor pode optar por expressar, em BPM, o andamento da música, que pode ser identificado por um metrônomo. Tal instrumento marca, com tique-taques, o número de tempos por minutos numa dada velocidade (BENNETT, 1998).
} 
Ainda de acordo com Copland (1974), apesar das diferentes aptidões que utilizamos para ouvir e compreender música, podemos distinguir e definir essa arte em três planos, a fim de analisar e visualizar, de forma mais concreta, os efeitos musicais.

O primeiro, o plano sensível, diz respeito às emoções que a música desperta; é a maneira mais simplista de escutar uma composição; é quando nos entregamos às sensações ao escutar uma música da qual gostamos sem pensar ou analisá-la, mas, ainda assim, nos deixando levar pelo sentimento que ela desperta em nós. Essa imersão passiva no som, que gera uma percepção sensível no que tange os sentimentos, é capaz de produzir um estado mental que não deve ser subestimado por ser desprovido de raciocínio intencional. "Imagine uma nota percutida no piano. Essa nota, por si só, é capaz de mudar a atmosfera da sala - o que prova que o elemento sonoro da música é um agente estranho e poderoso, que seria tolice subestimar" (COPLAND, 1974, p. 22).

O plano sensível é uma parte muito importante, porém apenas uma, de outras partes que compõem a forma como escutamos música.

O segundo, o plano expressivo (tido até mesmo por compositores como negável, inexistente ou refutável, muitas vezes pela dificuldade ou alta variedade de definições da expressão de uma peça musical), é basicamente o que a peça tem a dizer, seu significado que pode ser mais ou menos expressivo dependendo de diversos fatores, o que leva à crença de que é um plano refutável e controverso. A questão principal desse plano seria a impossibilidade de expressar em palavras concretas e gráficas uma expressão e significado que são altamente sensoriais e dificilmente gráficos. Podemos pensar de uma forma objetiva, ilustrando a questão, apontando para o fato de que a música não é uma história gráfica, passível de paráfrase, em que podemos explicar com outras palavras o que significa, uma vez que seus elementos dificilmente possuem sinônimos, o que é confundido com inexpressividade.

É nesse sentido que o autor nos apresenta a seguinte indagação:

[...] até onde deveria o ouvinte inteligente esforçar-se para identificar um determinado sentido na peça de sua preferência? [...] ele não deveria ir além de um conceito geral. A música expressa, em momentos diferentes, serenidade ou exaltação, tristeza ou vitória, fúria ou delícia.

Os temas ou obras completas não precisam, naturalmente, expressar uma única emoção. Tome, por exemplo, o primeiro tema importante da Nona Sinfonia. Ele 
é feito, claramente, de elementos distintos. Não diz apenas uma coisa. E, no entanto, quem quer que o ouça é afetado imediatamente por um sentimento de força e de poder. Esse poder não resulta simplesmente do fato de que o tema é tocado a um volume considerável; é um poder inerente ao próprio tema. A sua força extraordinária faz com que o ouvinte tenha a impressão de ter ouvido uma declaração da maior importância. Mas não deveríamos nunca confundir essa declaração com "o martelo implacável da vida" e coisas semelhantes. (COPLAND, 1974, p. 24-25)

O terceiro plano, puramente musical, abarca os elementos sonoros que se encontram na música de forma teórica. A melodia, o ritmo, a harmonia e os timbres são alguns dos elementos que compõe uma peça musical. É o material concreto que a música utiliza para sua reprodução que é tida de forma integrada, ou seja, tais elementos não ocorrem de forma distinta na reprodução de uma música.

Esses três planos são, então, percebidos pelo ouvinte de forma simultânea e instintiva. Porém, em especial o terceiro plano exige prática e conhecimento mais aprofundado para uma compreensão mais concreta.

\section{Retórica}

Em relação à retórica, lançaremos mão dos conceitos de Aristóteles, em Retórica (2015) e Ética a Nicômaco (2009), e dos ensinamentos de Olivier Reboul, em Introdução à retórica (2004), para compreender melhor o universo do pathos e poder relacioná-lo ao nosso corpus.

De acordo com Aristóteles:

A retórica [...] comporta três tipos de provas (pisteis) como meios de persuadir. Os dois primeiros são o ethos e o pathos [...]; constituem a parte afetiva da persuasão. $O$ terceiro tipo de prova, o raciocínio, resulta do logos, constituindo o elemento propriamente dialético da retórica. (ARISTÓTELES apud REBOUL, 2004, p. 36).

Ou seja, esses três pilares, dentro da retórica, delimitam e compreendem três instâncias capazes de analisar e classificar as matérias com que o orador argumentará junto ao seu auditório com vistas à persuasão e ao convencimento. $O$ ethos refere-se a todo tipo de matéria que circunda 0 caráter do orador - sua autoridade no assunto, imagem que passa ao auditório etc. -; o logos, todo material que compõe de alguma forma o discurso desse orador - provas; argumentos; histórias; assunto etc. -; e o pathos, qualquer elemento que reclame às emoções, as afecções que eclodem no auditório. Apesar de funcionarem em conjunto dentro de um discurso, 
neste artigo, adentraremos a instância do pathos, para compreender de que forma ele altera as engrenagens e circuitos da máquina humana.

Ainda sobre o pathos, Reboul (2004, p. 48) discorre: "O pathos é o conjunto de emoções, paixões e sentimentos que o orador deve suscitar no auditório com seu discurso". Visto que essa instância se refere à emoção, Aristóteles nos mostra que:

Uma vez que a retórica tem por objetivo formar um juízo [...], é necessário, não só procurar que o discurso seja demonstrativo e digno de crédito, mas também que o orador mostre possuir certas disposições e prepare favoravelmente o juiz (ARISTÓTELES, 2015, p. 159).

Se traduzirmos o termo juiz por auditório, compreenderemos que as emoções têm um grande papel na persuasão e que esse tipo de apelo ao pathos pode, portanto, se aplicar ao universo da sétima arte. No cinema, é comum que a produção almeje, de alguma forma, gerar a comoção no auditório e, nesse sentido, lança mão do jogo com as paixões com vistas a prender a atenção.

Uma vez compreendida a importância das emoções num gênero do discurso atual como o cinema, nos cabe depreender como essas emoções interferem na nossa existência; além de quantas são. Sobre seu funcionamento, Aristóteles mais uma vez nos ensina:

As emoções são as causas que fazem alterar os seres humanos e introduzem mudanças nos seus juízos, na medida em que elas comportam dor e prazer: tais são a ira, a compaixão, o medo, e outras semelhantes, assim como as contrárias (ARISTÓTELES, 2015, p. 160).

Então, as afecções - paixões - atuam na nossa existência prática, por meio de nossa disponibilidade a elas, causando-nos mal ou bem segundo suas possibilidades. As que comportam prazer lançam-nos em seu encalço, levando-nos a persegui-las por conta da sensação de bem-estar que causam. Já as que comportam dor lançam-nos no sentido contrário, fazendo-nos correr delas, pois nos causam o mal.

A seguir, faremos uma breve descrição de algumas das paixões aristotélicas que serão retomadas na análise, lembrando que estas não se dão por vícios ou virtudes permanentes da alma, mas, sim, por estados provados por emoções transitórias (ARISTÓTELES, 2015).

A calma: "pode ser definida como um apaziguamento e uma pacificação da cólera” (ARISTÓTELES, 2015, p. 167). É, portanto, entendida como o 
$\mathrm{El} \square \mathrm{dA}$

Revista Eletrônica de Estudos Integrados em Discurso e Argumentação, Ilhéus, n. 17, jul./dez. 2018

antídoto da ira, que, por sua vez "é um desejo acompanhado de dor que nos incita a exercer vingança explícita devido a algum desprezo manifestado contra nós, ou contra pessoas da nossa convivência, sem haver razão para isso" (ARISTÓTELES, 2015, p. 161). "Ela reequilibra a relação proveniente do ultraje, da afronta, do desprezo" (FIGUEIREDO; PERNAMBUCO, 2010, p. 4).

O amor:

Admitamos que amar é querer para alguém aquilo que pensamos ser uma coisa boa, por causa desse alguém e não por causa de nós. Pôr isto em prática implica determinada capacidade de nossa parte. É amigo aquele que ama e é reciprocamente amado. Consideram-se amigos os que pensam estar mutuamente nestas disposições.

Também são amigos aqueles que têm por boas e más as mesmas coisas, e por amigos e inimigos as mesmas pessoas. Daí resulta, forçosamente, querer para os amigos o que se deseja a si próprio; de modo que são amigos aqueles que, ao quererem para si o que querem para a pessoa amada, mostram com toda a evidência que são amigos dela. (ARISTÓTELES, 2015, p. 170).

O temor (medo): "consiste numa situação aflitiva ou numa perturbação causada pela representação de um mal iminente, ruinoso ou penoso" (ARISTÓTELES, 2015, p. 174).

Compreendidos, pois, os mecanismos das emoções na alma humana, partiremos para a análise do corpus para a constatação de nossa tese inicial, qual seja: a de que a trilha sonora pode exercer um papel significativo quando aliada às cenas no que tange às construções de sentido de uma peça cinematográfica.

\section{Análise}

A cena inicial, uma apresentação de fotos das lembranças do casal e suas famílias aos convidados, abre o episódio Até que a morte nos separe. Em meio às palmas, risos e pequenos diálogos, a música Titanium, da cantora australiana Sia Furler e do DJ francês David Guetta, inicia-se junto com as imagens.

A junção de imagem e som nesse momento pode suscitar a felicidade, euforia e alegria, sentimentos recorrentes em uma festa ou comemoração. As luzes dançantes, fotos dos momentos felizes do casal e sorrisos nos rostos dos convidados, remetem imageticamente aos sentimentos citados anteriormente. 
No que tange à canção, ela foi composta em compasso simples ${ }^{6}$ de $4 / 4 \mathrm{e}$ andamento "electro-pop" com 126 BPM. Com tais características, podemos denominar a peça como uma música de velocidade Allegro (em português alegre, vívido, feliz), de acordo com a nomenclatura de andamento musical.

Podemos, então, relacionar as imagens que se seguem e a música que acompanha as cenas com um sentimento alegre, por consequência com a felicidade. Para Aristóteles (apud CAEIRO, 2009, p. 15), a felicidade pode ser definida como "uma certa atividade da alma humana de acordo com a excelência completa", ou seja, o ser humano se sente feliz quando está completo, realizado. Ora, qual o momento mais tempestivo para sentir-se completo do que em uma festa de casamento? ${ }^{7}$ Os pais sentem-se completos por verem os filhos realizando-se no matrimonio, assim como os amigos e familiares; e os noivos sentem-se realizados por estarem unindo-se com alguém que irá completar sua existência.

Essas duas instâncias da película, ao criarem esse clima feliz de forma conjunta, podem projetar, na plateia, a felicidade tecida na trama, evocando esse estado de plenitude, uma vez que ele já estava disponível por meio da atmosfera previamente estabelecida pela junção de cenas e trilha sonora.

Ao passo que as cenas seguintes ficam mais eufóricas em torno da felicidade demonstrada imageticamente, a trilha sonora vai acompanhando tal sentimento, encaminhando a narrativa ao clímax da cena: momento em que os noivos adentram o salão de festas e são recebidos por seus familiares e amigos. Nesse instante, podemos notar que o som aumenta, ditando a emoção que o momento projeta no auditório, mais uma vez, podendo despertar a felicidade por meio da relação cena-trilha sonora.

A próxima música da trilha sonora invade o quadro, em conjunto com suas cenas, assim que a o trecho retórico-musical anterior termina, mantendo a atmosfera feliz e eufórica das cenas que se passam. Babel short and dialog, de Gustavo Santaolalla, é tocada com uma banda encenando sua reprodução. Em relação à música, podemos detectar que sua taxa de BPM fica entre 170180 , o que a enquadra como presto, de acordo com a nomenclatura italiana

6 Conforme partitura divulgada pela Universal Music Publishing Group. Disponível em: http://ekladata.com/2EWw_Zm-GU7dzZReilmswbPG-8E/-PVG-David-Guetta-Feat.-Sia-Titanium.pdf. Acesso em: 10 maio 2018.

7 "a felicidade necessita igualmente dos bens exteriores, pois é impossível, ou pelo menos não é fácil, praticar ações nobres sem os devidos meios. Em muitas ações usamos como instrumentos os amigos, a riqueza e o poder político [...] o homem feliz parece necessitar também desse tipo de prosperidade, e é por isso que algumas pessoas identificam a felicidade com a boa fortuna, embora outros a identifiquem com a virtude." (ARISTÓTELES, 2007, p. 9). 
apresentada. Tal termo tem como definição: "veloz e animado", o que pode ser relacionado aos diversos instrumentos que reproduzem a composição de Santaolalla - instrumentos de sopro com timbres fortes e metálicos - e também às cenas que transparecem euforia e animação. A junção de cena e trilha sonora, mais uma vez, pode projetar o clima criado no auditório, elevando seu estado de espírito e seguindo, assim, as emoções despertadas na narrativa.

Podemos notar uma progressão na narrativa, que aumenta a euforia e a felicidade das cenas, assim como da trilha sonora que as acompanham. Essa atmosfera viva e feliz, criada pela junção cena-trilha sonora, é quebrada instantaneamente quando o segundo trecho retórico-musical se encerra, o que nos dá uma visão mais ampla e mais profunda para o entendimento e significação dos Relatos Selvagens que se seguirão na intriga.

Aristóteles, em Ética a Nicômaco (2009), trata do espectro das paixões humanas e como tais afecções afetam nossa alma (psyche), que, segundo ele, possui três funções essenciais: a vegetativa, a sensitiva e a intelectiva. A parcela vegetativa (presente em todos os seres vivos) tem como intuito a nutrição, a reprodução e o crescimento; a parcela sensitiva (comum aos humanos e animais) tem por fito as sensações, os apetites e o movimento; e a parcela intelectiva (exclusiva aos humanos) é a parte racional da alma. Essas três funções da alma humana estabelecem, em circunstâncias ideais, diálogo e correlação, nos permitindo decidir e ponderar sobre nossas ações e decisões.

O transitar entre os polos emocionais contidos na narrativa desenha toda a trama de Relatos Selvagens, e especificamente a cena em questão - em que a dinâmica entre as imagens e a trilha sonora parte de um extremo ao outro - representando, assim, a luta que o intelecto (as cenas de choque diante os absurdos ocorridos, por exemplo) e o apetite sensível (as cenas em que as personagens deixam as emoções histéricas e desenfreadas dominarem suas ações sem pesar em seus atos, por exemplo) travam por toda a trama do filme.

Esse momento da quebra de dinâmica na relação cena-trilha sonora - da reprodução viva e eufórica de Babel short and dialog, com as personagens dançando e pulando, para quase o total silêncio do momento de diálogos entre os convidados, sentados e sóbrios sendo fotografados - traduz exatamente o caráter do indivíduo que deixa a batalha entre a razão e a emoção acontecer livremente dentro de si - ora o intelecto o torna impassível, 
ora o animal dentro dele dita suas ações e o instiga ao movimento. O episódio - assim como o filme de maneira geral - representa, então, por meio dessa relação cena-trilha sonora, o que há de selvagem dentro de nós.

$\mathrm{Na}$ medida em que os fatos se sucedem, após a cena sóbria de cumprimentos e fotografias, e a cena da noiva tomando consciência de que foi traída por seu marido, a trilha sonora volta a incidir sobre a trama, tecendo seus significados passionais. A próxima música, a valsa de Johann Strauss II, An der schönen, blauen Donau, inicia-se em meio ao desconforto da noiva. A junção da cena - a noiva que acaba de descobrir a traição de seu noivo, em sua festa de casamento [algo incomum; não tradicional e que traz uma atmosfera pesada] - com a música - uma valsa romântica interpretada por um conjunto de cordas [algo tradicional em uma festa de casamento e que traria um clima leve e confortável à cena] - confere um caráter irônico à trama. Sobre a ironia, Fiorin (2014, p. 69-70) nos ensina: "é um alargamento semântico, uma difusão sêmica. No eixo da extensão, um significado tem o seu valor invertido, abarcando assim o sentido x e seu oposto". Ou seja, algo que tenha um dado sentindo passa a abarcar o sentido oposto, confrontando os dois sentidos, o que causa o estranhamento, o desconforto e, assim, traz o caráter tragicômico da ironia à tona. E pode ser exatamente dessa maneira que a junção da cena com a trilha sonora projeta no auditório uma afecção de piedade em relação à noiva; a ironia do momento - uma música romântica, que representa o amor, contraposta à cena que exprime total ódio em função da traição - reafirma a relação cena-trilha sonora na projeção das emoções no auditório.

A trama se desenrola, e a noiva, desolada com a verdade arrancada de seu esposo, abandona sua festa indo parar no terraço do edifício que estava sediando a comemoração. Com os fatos que acontecem na cobertura do prédio, temos contato com dois elementos sonoros produzidos nas cenas que se seguem: o som de sirene da ambulância e o som do trovão. Tais efeitos sonoros, apesar de não pertencerem à trilha sonora propriamente dita, são de grande significado para nossa análise.

Ambos os sons podem emergir na consciência coletiva a paixão do temor - medo. No caso da sirene o medo emerge da relação com o perigo ao risco à vida que o som representa. Enquanto o trovão desperta o medo por sua relação de presságio da tempestade, do raio e da destruição. 
Esses dois medos coletivos foram muito bem explorados e se conectam de forma sublime ao campo imagético do episódio. O som da ambulância se conecta ao perigo visual da noiva pendendo sobre o parapeito do terraço do edifício, o que se alia ao temor coletivo do som e pode projetar com muito mais eficácia a paixão do medo no auditório: o medo da noiva despencar rumo à tragédia. Como decifrou Aristóteles (2015), sentimos o medo em relação a alguém que nos é querido ou com quem compartilhamos traços que coincidem entre si. No caso do medo que o auditório pode sentir pela noiva, ele deriva da relação de cumplicidade que os dois compartilham, isto é, a noiva e o público que está assistindo ao filme.

O som do trovão se conecta imageticamente ao monólogo vingativo da noiva (dirigido ao noivo infiel) e ao seu estado visual - descabelada, com a maquiagem borrada e visivelmente fora de sua razão. O medo coletivo da destruição da tempestade e dos raios alia-se, assim, ao temor possivelmente despertado pela tempestade corporificada no monólogo da personagem. Assim como o trovão é o presságio da tempestade, o discurso da noiva prediz as ações que ela desencadeia em seguida.

A narrativa, ao retornar para o salão de festas, traz as próximas músicas - e cenas - ao foco, suscitando, assim, mais conteúdo para a nossa análise. A noiva adentra o salão visualmente descompensada, como dito anteriormente, o que também é perceptível em suas ações. As músicas que tocam a seguir, Shalom Aleichem + Tema seguinte, possuem ambas o mesmo BPM: cerca de 160-168 (Vivacissimo). As duas são reproduzidas por instrumentos de timbres vibrantes e agudos - violino, teclado e percussão metálica - além de serem reproduzidas na narrativa em um volume elevado. Essas características trazem novamente o caráter aparentemente animado, eufórico e vivo das músicas à festa. Juntando esse sentimento eufórico expressado pela trilha sonora com os fatos trágicos e emoções de ira e temor despertados pelos acontecimentos imagéticos temos novamente a aparição da ironia.

A contradição, da música animada, do momento festivo da celebração, com os fatos trágicos da traição e atos da noiva - contra a amante de seu marido - conferem a ironia à cena, podendo evocar o riso nervoso, peculiar dessa figura retórica. No que concerne às paixões aristotélicas, a cólera da noiva pode ser projetada, por meio da relação cena-trilha sonora, no auditório, que, uma vez compadecido e cúmplice das desventuras da noiva, brada à vingança que está por vir. 
Assim que as emoções dominam os noivos - e seus familiares -, a tragédia se instala na narrativa e o episódio se encaminha para o final. Na cena de encerramento, os noivos, após toda a barbárie, reconciliam-se, e a última canção é reproduzida, concluindo, assim, nossa análise da relação cena-trilha sonora.

Ao darem as mãos, fazendo as pazes, a música Fly me to the Moon, de Bobby Womack, uma canção $R \& B$, começa a tocar. A canção traz a interpretação de Womack, que possui um timbre acalorado e, ao mesmo tempo, rouco que dá o tom quente e passional da canção. Seguido por um arranjo clássico de $R \& B$ - contrabaixo marcado e percussão seguindo o compasso do baixo, com instrumentos jazzísticos de sopro e acordes de guitarra, além de um violino que dá ainda mais abertura ao ar romântico -, com cerca de 110 BPM a música se enquadra no andamento Andatino, classificado como agradável e compassado. Por essas características, a música se incorpora às cenas que apresentam a reconciliação do casal - momento do arrefecimento da cólera, do ódio e de todas as emoções que implicam dor - e podem suscitar a paixão da calma ao auditório, que lembremos é "[...] um apaziguamento e uma pacificação da cólera” (ARISTÓTELES, 2015, p. 167). Assim, podemos afirmar que, imageticamente, na peroração do episódio, as cenas vão ao encontro da trilha sonora e mostram os noivos acalmando seus ânimos, até que retornam à razão e, aparentemente, se rendem à paixão do amor.

Podemos concluir, então, que a relação cena-trilha sonora, nesse momento, pode projetar a paixão da calma no auditório; assim como a intriga, aliada a todas as situações testemunhadas, pode levar o espectador ao riso. Sobre essa variação da paixão da calma, aliada ao riso, discorre Aristóteles (2015, p. 159-160): “Os fatos não se apresentam sob o mesmo prisma a quem ama e a quem odeia, nem são iguais para o homem que está indignado ou para o calmo, mas, ou são completamente diferentes ou diferem segundo critérios de grandeza". Ou seja, uma paixão, que teoricamente poderia despertar a calma no auditório, traz consigo uma nova nuance - o riso. Isso se dá, porque, para o auditório que presenciou toda a trama do episódio, é possível que a paixão da calma, instigada pela relação cena-trilha sonora da peroração, seja interpretada por um novo ângulo, já que sua hierarquia de valores pode ter sido rearranjada em função da trama testemunhada.

E, assim, o último episódio de Relatos Selvagens se encerra, mostrando que as paixões contidas nele - e na junção de cena + trilha sonora - são 
$\mathrm{El} \square \mathrm{dA}$

Revista Eletrônica de Estudos Integrados em Discurso e Argumentação, Ilhéus, n. 17, jul./dez. 2018

multifacetadas e pluralizadas. Isso reflete muito do nosso cotidiano, uma vez que estamos em meio a diversas emoções que se enfileiram para tomar conta do nosso juízo e, às vezes, despertam nosso lado animalesco, assim como a película retrata com especial sagacidade.

\section{Considerações finais}

Ponderando nossa análise é possível concluir que, pelo menos no universo fílmico analisado, a música é capaz de aliar-se a outras linguagens em prol do despertar das paixões, fazendo o auditório se compadecer das personagens em função dos acontecimentos que a trama as submete. Dessa maneira, como buscamos demonstrar, as emoções da intriga se projetam no auditório.

Essa conclusão evidencia o poder que a música pode exercer sobre nós. Mesmo inerente à nossa existência, esse poder tem sido pouco explorado, documentado e discutido. Esse artigo almejou, então, investigar esse caráter retórico da música, que, apesar de se encontrar tão negligenciado, detém capacidades persuasivas altamente promissoras para as diferentes esferas do discurso multimodal.

\section{Referências}

ARISTÓTELES. Retórica. Tradução do grego por Manuel Alexandre Júnior, Paulo Farmhouse e Abel do Nascimento Pena. São Paulo: Folha de S. Paulo, 2015. (Coleção Folha. Grandes nomes do pensamento; v. 1).

. Ética a Nicômaco. Tradução do grego de António de Castro Caeiro. São Paulo: Atlas, 2009.

. Ética a Nicômaco. Tradução Pietro Nassetti. São Paulo: Martin Claret, 2007. Disponível em: https://filosofiauerj.files.wordpress.com/2007/05/etica-a-nicomacoaristoteles.pdf. Acesso em: 25 out.2018.

. The metaphysics of Aristotle. Translated from the Greek by Thomas Taylor. London, 1801.

BENNETT, Roy. Elementos básicos da música. Tradução Maria Teresa R. Costa. Rio de Janeiro: Jorge Zahar Editor Ltda., 1998.

CAEIRO, António. Prefácio. In: ARISTÓTELES. Ética a Nicômaco. Tradução do grego de António de Castro Caeiro. São Paulo: Atlas, 2009. p. 9-15. 
$\mathrm{El} \square \mathrm{dA}$

Revista Eletrônica de Estudos Integrados em Discurso e Argumentação, Ilhéus, n. 17, jul./dez. 2018

COPLAND, Aaron. Como ouvir (e entender) música. Tradução: Luiz Paulo Horta. Rio de Janeiro: Artenova, 1974.

FIGUEIREDO, Maria. Flávia; PERNAMBUCO, Juscelino. Paixões em primeira página: análise linguística de manchetes de jornal. In: $13^{\circ}$ Congresso Brasileiro de Língua Portuguesa e $4^{\circ}$ Congresso Internacional de Lusofonia do IP/PUC-SP, 2013, São Paulo, SPP. Anais do $13^{\circ}$ Congresso Brasileiro de Língua Portuguesa e $4^{\circ}$ Congresso Internacional de Lusofonia do IP/PUC-SPP. São Paulo: PUC, 2010. p. 1-11.

FIORIN, José Luiz. Figuras de retórica. São Paulo: Contexto, 2014.

GUETTA, David; FURLER, Sia. Titanium. Los Angeles: Universal Music Publishing Group, 2011. 1 CD (4min). Disponível em: http://ekladata.com/2EWw_ZmGU7dzZReilmswbPG-8E/-PVG-David-Guetta-Feat.-Sia-Titanium.pdf. Acesso em: 10 maio 2018.

MALHADAS, Daisi. Tragédia grega: o mito em cena. Cotia: Ateliê Editorial, 2003.

MARTINS, Francisco. O que é phatos? Revista Latinoamericana de Psicopatologia Fundamental, São Paulo, v. 2, n. 4, p. 62-80, out./dez. 1999.

MEYER, Michel. Prefácio. In: ARISTÓTELES. A retórica das paixões. Tradução: Isis Borges B. da Fonseca. São Paulo: Martins Fontes, 2000. p. XVII-LI.

REBOUL, Olivier. Introdução à retórica. Tradução: Ivone Castilho Benedetti. 2. ed. São Paulo: Martins Fontes, 2004.

RELATOS Selvagens. Direção: Damián Szifron. Produção: Pedro Almodóvar, Agustín Almodóvar, Hugo Sigman, Esther García, Matías Mosteirín. Roteiro: Damián Szifron. Música: Gustavo Santaolalla. Argentina/Espanha, Warner Bros, 2014. 1 DVD (122 min), widescreen, color. Produzido por Kramer \& Sigman Films, El Deseo e Warner Bros. Pictures International.

\section{Forma de citação sugerida}

SANTOS JUNIOR, Valmir Ferreira dos; FIGUEIREDO, Maria Flávia. O teclado das paixões em cena: Relatos Selvagens e o elo retórico-musical. EID\&A - Revista Eletrônica de Estudos Integrados em Discurso e Argumentação, Ilhéus, n. 17, p. 141157, jul./dez.2018. DOI dx.doi.org/10.17648/eidea-17-1988. 